\title{
A COMPARATIVE APPROACH TO ANALYZING LOCAL EXPENDITURES AND VISITOR PROFILES OF TWO WILDLIFE FESTIVALS
}

\author{
GLEN T. HVENEGAARD* and VARGHESE MANALOOR $\dagger$
}

*Department of Science and †Department of Social Sciences, Augustana Faculty, University of Alberta, Canada

\begin{abstract}
Wildlife festivals are growing in popularity and warrant additional studies of festival visitors. However, comparisons of visitor demographics, motivations, activities, and local expenditure patterns between festivals are difficult because different methods of measurement are used. By using a comparative approach, this study evaluates, with the same methods, the visitor characteristics of two similar wildlife festivals in Western Canada. While providing site-specific context, this study notes variations in total local expenditure patterns, visitor motivations, and visitor activities that result from, in part, different visitor demographics, activities offered, other attractions, and rates of overnight stays. Visitors to these festivals were slightly older age and had high educational levels than the general public, which was consistent with visitors to other wildlife festivals and ecotourists in general.
\end{abstract}

Key words: Wildlife festival; Birds; Expenditures; Economic impact; Visitor characteristics

Introduction

The number of wildlife festivals has grown rapidly across North America. Ten birding and nature festivals were offered in 1992 (Decray, Green, \& Payne, 1998; DiGregorio, 2002), but by 1999, there were over 150 birding festivals and 70 nature festivals (National Fish and Wildlife Federation, 1999). By 2002, the number grew to 240 (DiGregorio, 2002). Wildlife festivals, with a focus on local natural wildlife features, are often annual events, last 1-7 days, are facilitated by volunteers, and offer a variety of social, recreational, educational, and competitive activities.
Communities and not-for-profit organizations organize festivals for a variety of reasons; these include providing recreational opportunities, highlighting local natural or cultural heritage, enhancing a community's image, promoting local economic impact, and encouraging the tourism industry (Gursoy, Kim, \& Uysal, 2004). In addition, through their educational mission, wildlife festivals can build political, local, and financial support to conserve wildlife and their habitats (Millar, 2003; Romero \& Stangel, 1996). However, much attention is paid to the real and perceived economic benefits (Long \& Perdue, 1990; Uysal \& Gitelson, 1994) and visitor demographics. 
Previous studies have demonstrated the local economic impact of wildlife festivals in Texas (Kim, Scott, Thigpen, \& Kim, 1998), California (Fermata, Inc., 2001), and Florida (Chambliss, Slotkin, \& Vamosi, 2005; Lynch, Harrington, Chambliss, Slotkin, \& Vamosi, 2003). Most economic impact studies document expenditures in the local area of the host community by nonresidents. For example, visitors spent US\$33-184 per person at wildlife festivals in California (Fermata, Inc., 2001) and US\$14 at a wildlife festival in Florida (Lynch \& Harrington, 2003). Some studies also estimate indirect and induced economic impacts (e.g., Chambliss et al., 2005; Kim et al., 1998), and provide estimates of economic multipliers.

Economic studies also use other methods to estimate nonmarket values (Portney, 1994). The Contingent Valuation Method (CVM) is a popular method, but is not without controversy. For example, CVM respondents may be unwilling to give meaningful responses to questions about wildlife (Stevens, Echeverria, Glass, Hager, \& More, 1991). Nevertheless, two studies have estimated wildlife festival participants' consumer surplus for direct use value, which measures the visitors' maximum willingness to pay to make the trip. These values ranged from US $\$ 45$ to $\$ 149$ per trip in two California festivals (Fermata, Inc. 2001) and \$205 per trip in a Texas festival (Eubanks \& Stoll, 1999).

Demographically, wildlife festival participants tend to be very educated, with most studies showing 40$70 \%$ having obtained at least a bachelor's degree (Burr \& Scott, 2004; Chambliss et al., 2005; Kim et al., 1998; Lynch et al., 2003). Festival participants tend to be slightly older than the general population; the proportion of participants aged 65 years and older ranges from 9\% (Lynch \& Harrington, 2003) to 30\% (Chambliss et al., 2005). Females are more likely to participate than males, with female participation rates usually between $50 \%$ and $60 \%$, but as high as $77 \%$ (Kim et al., 1998). In past studies, the percentage of nonresidents ranges widely, from 10\% (Lynch \& Harlington, 2003) to $73 \%$ (Lynch et al., 2003) of wildlife festival visitors. Motivations for visitors to attend wildlife festivals depended greatly on the activities and attractions of each festival (Chambliss et al., 2005; Fermata Inc., 2001) and the level of recreation specialization of the visitor (Burr \& Scott, 2004).

The benefits, costs, and visitor characteristics associated with any festival need careful analysis in order to effectively plan for, manage, and evaluate overall net impact. Such an analysis is aided by each festival's context. For example, variables such as community size, attendance, visitor activities, and length of stay, among others, strongly influence these impacts (e.g., Chhabra, Sills, \& Cubbage, 2003). Most studies of wildlife festivals provide this contextual information in isolation (with the exception of Fermata, Inc., 2001). Given the limitations of case study approaches to event research (Nicholson \& Pearce, 2000), comparative studies can provide new ways of understanding festival dynamics (Fisby \& Getz, 1989).

The comparative study approach has been used in the broader tourism literature (Baum, 1999), but has "yet to emerge as a distinctive, readily recognizable methodology in tourism research" (Pearce, 1993, p. 20). Comparative studies seek out explanation or generalization of "phenomena in two or more contexts" (p. 22), over either place or time (Warwick \& Osherson, 1973). Baum (1999) identifies several benefits from comparative research, including the ability to estimate longitudinal trends, assess similar destinations, identify new marketing strategies, benchmark against various criteria, learn from experiences, and improve understanding of specific events. On the other hand, limitations of this approach include ambiguous definitions, variable data, research methods that vary by discipline, and diversity of tourism's subsectors (Baum, 1999).

Although comparisons of festival activities and characteristics can be done on a case by case basis, comparative studies are rare because research settings often have little in common that can provide a starting point for scrutiny. As well, studies have different research methods, survey questions, and analyses. A "most similar systems approach" reduces problems in comparing sites (Pearce, 1993, p. 22) by choosing sites with similar characteristics and applying a common methodology (Warwick \& Osherson, 1973). A unique comparative opportunity is available in Western Canada, with the Beaverhill Lake Snow Goose Festival in Tofield, Alberta and the Brant Wildlife Festival in Parksville-Qualicum Beach, British Columbia. These two festivals, with similar characteristics (e.g., size, target species, types of activities, frequency, timing, and demographics of host population) were investigated with the same methodology. Thus, the goal of this study is to deepen our understanding of two similar wildlife festivals by comparing local expenditures, and visitor activities, motivations, and demographics. 
Study Sites and Methods

The 2-day annual Snow Goose Festival began in 1993 and is hosted by Tofield (population 1,800), located about $60 \mathrm{~km}$ southeast of Edmonton (population about 1 million), Alberta. In late April, nearby Beaverhill Lake attracts thousands of Snow Geese and other birds on their northward, spring migration. At its peak, the festival attracted 3,000 to 7,000 people. Participants take part in a variety of activities: nature center visit, guided bus tour, guided hike, wildlife trade show, art show, or nature's market. Surveys for this study occurred April 29-30, 2000, when the festival attracted an estimated 5,000 visitors. The festival was reduced substantially from 2003 to 2005, as drought lowered the water levels in the lake and forced the Snow Geese to other locations. The festival was renamed the Spring Nature Festival in 2006.

The Brant Wildlife Festival began in 1991 and is hosted by the Parksville-Qualicam Beach region (populations of 6,900 and 10,300, respectively) located about $37 \mathrm{~km}$ north of Nanaimo (population about 85,000), British Columbia. The festival celebrates the spring arrival of the Pacific Black Brant Goose and other wildlife into this region with unique ecosystems and high biodiversity (Ward, Radcliffe, Kirkby, Illingworth, \& Cadrin, 1998). Over 3 days in early April, participants can join wood carving and birding competitions, art exhibitions, nature tours, art and photography workshops, and other family activities. Surveys for this study took place April 4-6, 2003 when the festival attracted an estimated 3,430 visitors.

For both festivals, participants aged 16 years and older were invited to complete a 5-minute questionnaire. At each festival, surveys were randomly distributed from at least seven venues, including staging areas, display sites, art and trade shows, information centers, and other activity foci. The only differences in these questionnaires related to site-specific activity questions. Overall, 1,038 (74\% response rate) and 131 (31\% response rate) visitors completed forms were collected at the Snow Goose and Brant Festivals, respectively. The Snow Goose Festival had a higher sample size because the visitors were concentrated in one small town with readily accessible venues, whereas the Brant Festival was spread out between two larger communities, with more dispersed venues. The total number of visitors was determined by counting registrants for guided bus tours and hikes, and by organiz- ers estimating visitation at other venues. Surveys asked respondents about their demographics, motivations, activities, current trip, per person expenditures, and potential purchases. Respondents were asked to estimate their total per person expenditures for their entire festival trip and the amount spent in the local areas. Expenditure estimates were weighted by resident versus nonresident status and registered versus nonregistered status of visitors. Nonresident visitors (defined as living farther than $25 \mathrm{~km}$ from the host community) were noted because it is this group that brings new money into a region, whereas resident visitors would likely have spent money in the region regardless of the festival. Registered visitors signed up for events before the festivals, often paying a fee. While important in more detailed economic impact analyses, we did not attempt to measure multipliers or indirect and induced expenditures.

\section{Results}

All Snow Goose visitors spent an estimated total of CA $\$ 98,050$ in the local area, whereas Brant visitors spent CA $\$ 534,188$ in the local area. Of the Snow Goose visitors, $96.8 \%$ were nonresidents, and $63.0 \%$ of the Brant visitors were nonresidents. Compared to the Brant Festival, the Snow Goose Festival attracted more visitors from within the province and fewer from other provinces and countries (Table 1).

Despite attracting fewer visitors, the Brant Festival resulted in greater local expenditures by nonresidents (CA $\$ 336,544)$ than the Snow Goose Festival (CA \$84,840). The average local expenditure for nonresident Brant visitors was over eight times greater than for Snow Goose visitors (CA $\$ 155.73$ vs. CA $\$ 17.53$ ). Nonresident Brant visitors spent much more locally than Snow Goose visitors in the categories of accommodation, restaurants, groceries, registration, entertainment, and other costs. Expenditures were larger even for the categories related to travel and souvenirs (Fig. 1).

Table 1

Visitor Profile: Where Do They Come From?

\begin{tabular}{lcc}
\hline Origin & Snow Goose Festival & Brant Wildlife Festival \\
\hline From within province & $96.3 \%$ & $88.6 \%$ \\
From other provinces & $1.7 \%$ & $9.3 \%$ \\
From outside Canada & $2.0 \%$ & $2.1 \%$ \\
\hline
\end{tabular}




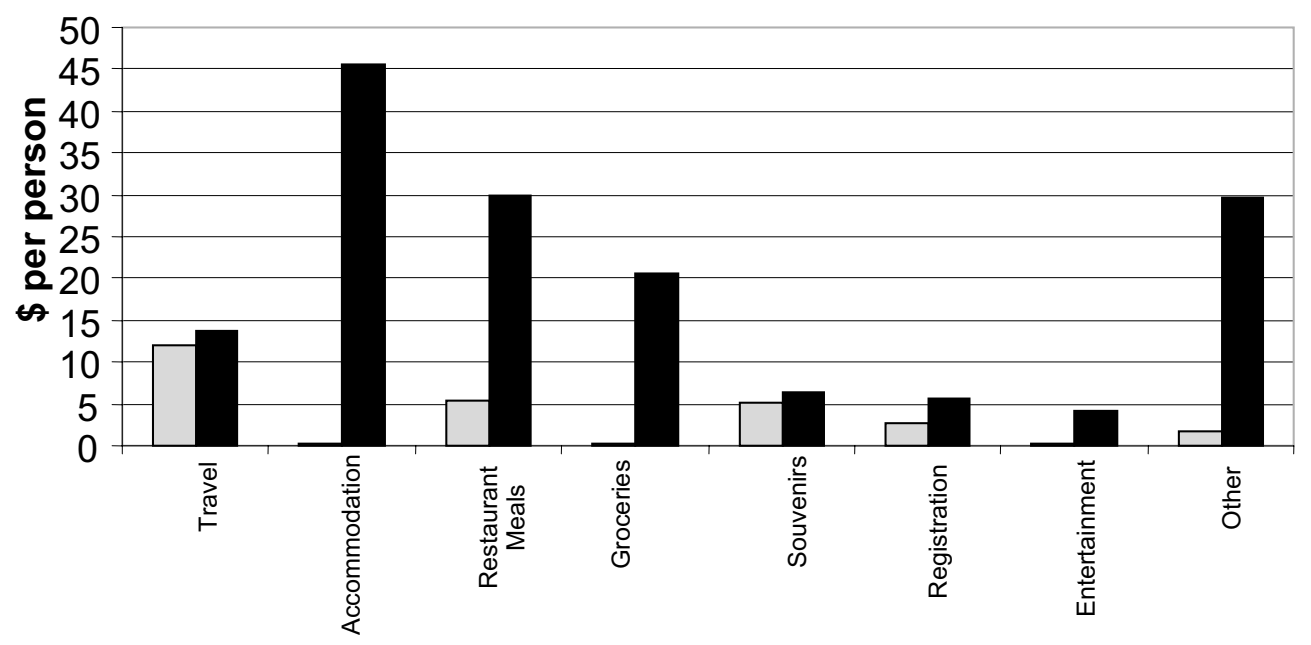

\section{Snow Goose Festival $\quad$ Brant Wildlife Festival}

Figure 1. Comparison of local expenditures incurred by nonresident visitors.

We asked visitors at both festivals what products and services they would have purchased if they had been made available (Fig. 2). We received 82 responses from Snow Goose visitors and 23 from Brant visitors. The most common responses for Snow Goose visitors were souvenirs, food, birding supplies, clothes, and books. For Brant visitors, the most common responses were food, carving supplies, followed by souvenirs, birding supplies, books, and tours.
Brant visitors (29.2\%) were much more likely to stay in local overnight accommodation than Snow Goose visitors (1.5\%). More Brant visitors than Snow Goose visitors came from out of province (11.4\% vs. 3.7\%). As well, most Snow Goose visitors drove to the site, stayed for all or part of a day, and then returned home or to the large nearby city of Edmonton.

The festivals were a key driver of visitor motivations and activities. The festival was the main reason for al-

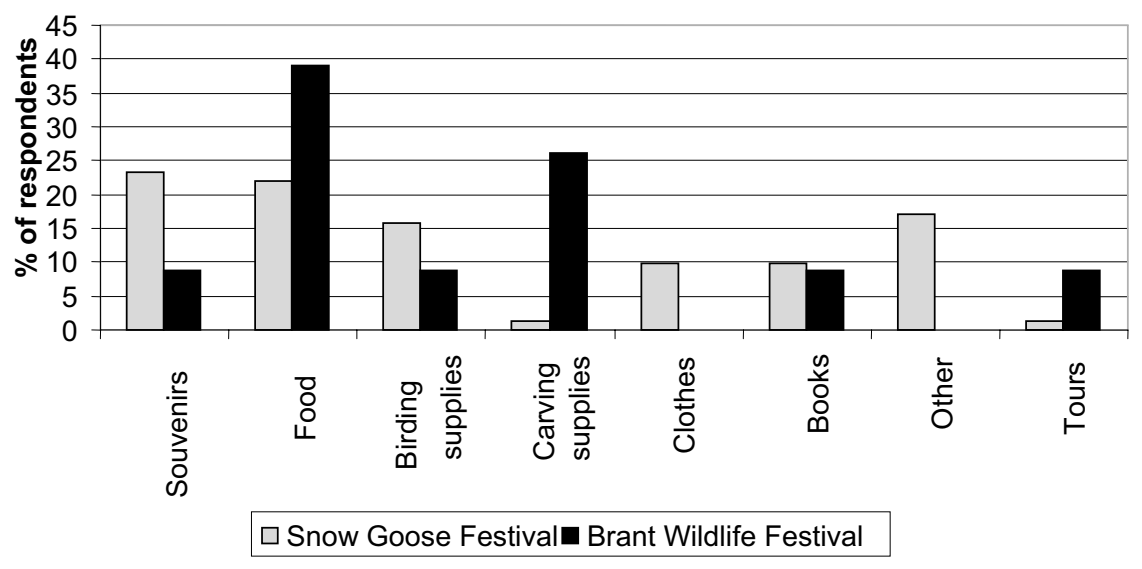

Figure 2. Comparison of products and services that would have been purchased by festival visitors. 
Table 2

Visitor Profile: What Is Your Main Motivation for Attending the Festival?

\begin{tabular}{lcc}
\hline Motivation & $\begin{array}{c}\text { Snow Goose } \\
\text { Festival }\end{array}$ & $\begin{array}{c}\text { Brant Wildlife } \\
\text { Festival }\end{array}$ \\
\hline Social outing & $36.3 \%$ & $19.8 \%$ \\
Learn about geese & $20.8 \%$ & $18.7 \%$ \\
Improve birding skills & $16.3 \%$ & $14.3 \%$ \\
To be outdoors & $9.6 \%$ & $11.0 \%$ \\
Photograph geese and other birds & $7.4 \%$ & $6.6 \%$ \\
Wood carving & $\mathrm{n} / \mathrm{a}$ & $29.7 \%$ \\
\hline
\end{tabular}

most all Snow Goose visitors (97.9\%) to visit the area, but only for $68.7 \%$ of Brant visitors. Snow Goose visitors were more motivated by having a social outing than Brant visitors (Table 2). When asked about their main motivation for attending the festival, the most important motivations for Brant and Snow Goose visitors were wood carving and having a social outing with friends and family, respectively. Motivations related to learning about geese, improving birding skills, and being outdoors were important for similar proportions of visitors at each festival. Finally, the most popular activity at the Brant Festival was wood carving $(56.2 \%$ of respondents), whereas the most popular activity at the Snow Goose Festival was a guided tour $(65.5 \%$ of respondents).

The Snow Goose Festival attracted more first-time visitors (65.8\%) than the Brant Festival (43.3\%). Snow Goose visitors were much less likely to return to the area within a year $(49.2 \%)$ than Brant visitors $(81.0 \%)$.
Figure 3 shows the demographic characteristics of respondents. Snow Goose visitors were more likely to be female $(61 \%)$ than Brant visitors (48\%). The Brant festival had a greater proportion of visitors older than 60 years of age and a lesser proportion of visitors younger than 40 years of age than the Snow Goose Festival. Snow Goose visitors were more likely to have earned a university degree than Brant visitors.

\section{Discussion}

Comparing events with similar characteristics and with the same methodology provides a unique opportunity to draw lessons in tourism research in general (Baum, 1999), and to gain insights into the dynamics of festival activities, participants' demographics, and local impacts. First, both Western Canadian festivals examined in this study are held annually in April, during the spring migration. Second, both festivals target large waterfowl species (Snow Geese and Brant) that are abundant in the local area during that time. Third, both festivals attract similar sized audiences. Fourth, both studies were conducted within 3 years of each other and used the same questions, sampling methodology, and analyses. Finally, the host populations had similar demographic characteristics. For example, the median income of persons 15 years of age and over is CA $\$ 18,021$ for Parksville and CA $\$ 21,850$ for Qualicum Beach, the cohosts of the Brant Festival. This compares reasonably well with the median income of CA $\$ 18,408$ in Tofield, the host of the Snow Goose Festival (Statistics Canada, 2006a). The gender distribution in the two

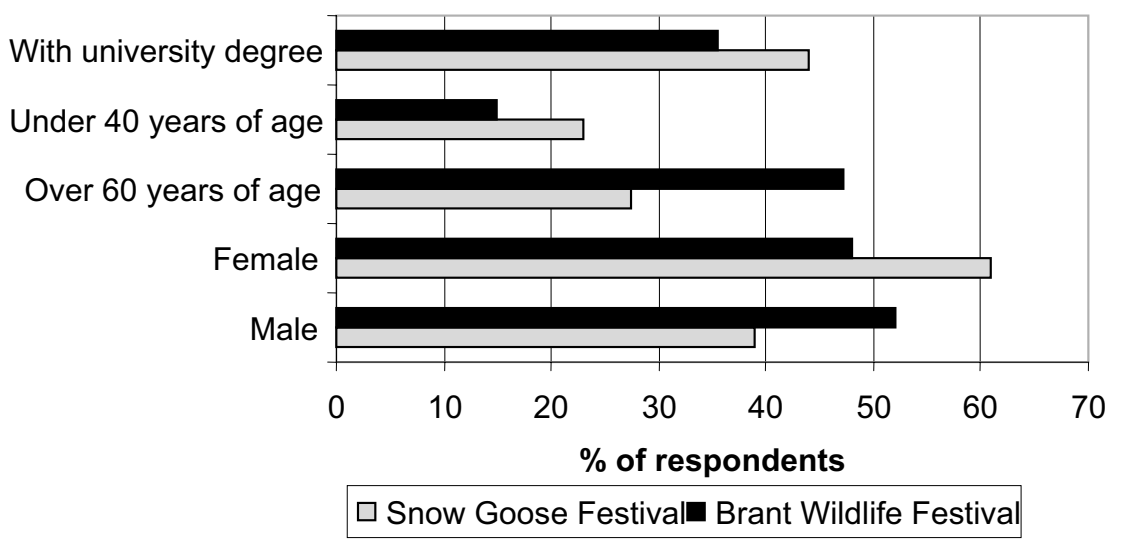

Figure 3. Comparison of education, age, and gender by festival visitors. 
study regions is identical with $46 \%$ males and $54 \%$ females (Statistics Canada, 2006a). A good understanding of festival similarities and differences can provide organizers with valuable information with which to plan and manage future events. This is made easier when the studies employ common questions, sampling methodologies, and analyses.

While other benefits from these wildlife festivals were not measured, festival expenditures in the local communities were considerable. Despite attracting fewer visitors, Parksville-Qualicum received more local expenditures than Tofield because Brant festival visitors spent much more per person than Snow Goose visitors. The expenditure categories that varied most between festivals were related to accommodation, restaurants, groceries, and entertainment. The levels of expenditures per person estimated at these festivals are similar to other 2-day festivals. For example, Fermata, Inc. (2001) estimated the local expenditures (including nonresidents) for the American River Salmon Festival and Kern Valley Bioregions Festival, both in California, to be US\$33.80 and US\$184.15, respectively, per visitor. Similarly, the Florida Wakulla springs Birding and Wildlife Festival resulted in US\$14.15 per person (including nonresidents) in local expenditures (Lynch \& Harrington, 2003).

The expenditure differences at the two festival sites can be attributed, in part, to the following four factors. First, the Brant Festival drew more visitors from out of province than the Snow Goose Festival. This pattern resulted in greater distances traveled for Brant visitors, creating a need for overnight accommodation and restaurant or grocery food. Second, a major activity at the Brant Festival, a wood carving competition, required participation over 2 days (demonstration day with judging and awards the next day), whereas the Snow Goose Festival involved mainly a 1-day visit. This difference is important in terms of the total expenditures (and types) in an area; the greatest impact from multipleday festivals comes from lodging expenditures, whereas the greatest impact from 1-day festivals comes from food and beverage expenditures (Chhabra et al., 2003). Third, given their relative sizes, Tofield has far fewer services (e.g., restaurants, hotels) and other visitor attractions than Parksville-Qualicum, which already has a reputation as a tourist destination. Finally, the elderly nature of the Brant Festival visitors likely indicates a greater reliance on, and expenditures for, hotel accommodation. Overall, Brant visitors are willing to travel greater distances, stay longer, and spend more in the local area than Snow Goose visitors. This may be a result of providing the types of activities (e.g., guides, venues, viewing opportunities) desired by visitors.

Total local expenditures by nonresident visitors suggest that Parksville-Qualicum is receiving greater benefits than Tofield from their respective festivals. However, one can also examine total expenditures per resident in the local communities. With this analysis, Tofield receives about CA $\$ 47$ of festival expenditures per resident $(\$ 84,840 / 1,800)$, while ParksvilleQualicum receives about CA $\$ 20$ per resident $(\$ 336,544 / 17,200)$. The impact on a per resident basis is more significant in a smaller community than a larger one. We did not estimate indirect or induced expenditures, nor did we estimate multipliers. This would be necessary to determine the total economic impact of these festivals, although the relative impacts would not be expected to change greatly.

Visitors at both festivals were willing to spend more in the local region if products and services had been available. Responses common to both festivals were souvenirs, food, books, and birding supplies. Brant visitors, in particular, would have spent money on carving supplies to support the focal activity, a wood carving competition. Both communities could have received more local economic input if they had made these desired products and services available to visitors. Other studies of wildlife festivals have not measured this potential. However, birders at Point Pelee National Park would have been willing to pay an average of CA $\$ 78$ per person in 1987 for desired products and services, had they been available (Hvenegaard, Butler, \& Krystofiak, 1989).

Travel characteristics of festival visitors reveal further differences between these sites. Even though the Brant Festival attracted a lower proportion of nonresidents than the Snow Goose Festival (63\% vs. 96\%), it still attracted a higher proportion of visitors from out of province ( $11 \%$ vs. $4 \%)$. The proportion of nonresidents for other studies of wildlife festivals ranges from $10 \%$ (Lynch \& Harrington, 2003) to $71 \%$ (Kim et al., 1998). The dynamics of local populations and types of activities provide some explanation. First, Tofield is located in a relatively unpopulated region of rural Alberta, with a very small local population from which to draw visitors. Parksville-Qualicum, on the other hand, is located in a relatively populated region of Vancouver Island, with many retirees with time and interest to at- 
tend its festival. Second, the wood carving competition at the Brant Festival draws people from long distances, raising the proportion of visitors from out of province. Unlike Tofield, tourism is the major economic activity in Parksville-Qualicum Beach region. It is a major tourist destination as well as a major tourist node. People stop off at Parksville-Qualicum on their way to northern areas of Vancouver Island or when traveling out to the West Coast and perhaps take in the Brant festival as part of their onward travel destinations.

Motivation and activity patterns also differed between festivals. First, the festival was the main reason for visiting the local community for $97.9 \%$ of Snow Goose visitors and $68.7 \%$ of Brant visitors. One possible explanation is that Parksville-Qualicum offers many more attractions than Tofield, besides the wildlife festival. Second, Snow Goose visitors were most motivated by having a social outing (36.3\% of respondents), whereas Brant visitors were most motivated by the wood carving display and competition $(29.7 \%)$. Third, this is reinforced by the most common festival activities: guided tours at the Snow Goose Festival (65.5\% of respondents) and wood carving at the Brant Festival (56.2\%). Finally, Snow Goose visitors were newer to bird watching and to the Snow Goose Festival $(65.8 \%$ vs. $43.3 \%$ were first-time visitors) than Brant visitors. This is consistent with the less focused motivations (social outing and learning versus the wood carving) among Snow Goose visitors.

Comparisons with other festivals are difficult because other studies measure motivations differently (e.g., Burr \& Scott, 2004; Chambliss et al. 2005). However, festival visitor characteristics reveal differences along the recreation specialization continuum, originally conceptualized by Bryan (1977), and later operationalized for birders (e.g., Hvenegaard, 2002; McFarlane, 1996) and wildlife festival visitors (e.g., Scott \& Thigpen, 2003). Snow Goose visitors correspond well with McFarlane's (1996) casual and novice specialization categories, whereas the Brant visitors correspond better with McFarlane's intermediate and advanced categories, in terms of experience, repeat visitation, and some motivations. Similarly, advanced birders attending the Texas Hummer/Bird Celebration were more likely to attend future versions of the festival than were less advanced birders (Scott \& Thigpen, 2003). This is consistent with the more experienced Brant visitors being more likely to attend future festivals than the less experienced Snow Goose visitors. By comparison, $46.6 \%$ of visitors to the Space Coast Birding \& Wildlife Festival had attended previously and $73.1 \%$ planned to attend the festival the next year (Chambliss et al., 2005).

Brant visitors were much more likely to return to the area within a year than Snow Goose visitors. This may reflect Brant visitors' interest in, and/or commitment to, the focal activity of wildlife carving. It may also reflect fewer attractions and a less developed tourism industry in the Tofield area than in the ParksvilleQualicum area. This is supported by the lower proportion of Brant visitors than Snow Goose visitors for whom the festival was the main reason for their visit. Put another way, $31 \%$ of Brant visitors were motivated to visit the area by reasons other than the festival, whereas this was true for only $2 \%$ of Snow Goose visitors.

The demographics of these festival visitors are similar to studies of other wildlife viewers (Wiedner \& Kerlinger, 1990). Among wildlife festival studies, the gender balance ranges from $52 \%$ female (Fermata, Inc., 2001) to $77 \%$ female (Kim et al., 1998), which means that the Brant Festival has the lowest proportion of females yet recorded. The Brant Festival also attracts more elderly visitors than other festivals (e.g., Chambliss et al., 2005, Lynch et al., 2003). One possible reason for this could be the fact that Brant festival attracts more local residents that are elderly. In the ParksvilleQualicum region, $48 \%$ of the population is over 55 years of age in comparison to $38 \%$ for Tofield (calculated from Statistics Canada, 2006a). Compared to other festivals, the proportion of visitors with a bachelor's degree is low for both the Brant and Snow Goose Festivals (and is also low for another Canadian festival-the Celebration of Swans; Yukon Department of Environment, 2006). Overall, however, both sets of festival visitors are more educated than the Canadian population (15.4\% of Canadians held a bachelor's degree in 2001; Statistics Canada, 2005). As well, both sets of festival visitors were older than the Canadian population $(21.6 \%$ of Canadians 15 and older are over 60 years of age; calculated from Statistics Canada, 2006b). Given their education levels, and likely affluence, of both sets of visitors, local expenditures could rise considerably if desired goods and services were made available in the local communities.

The Snow Goose Festival attracted a greater proportion of female visitors, a greater proportion of younger visitors, fewer older visitors, and more visitors with a university education than the Brant Festival. The older 
age among Brant visitors is supported by the large number and proportion of retired people living in the Parksville-Qualicum area. The educational difference may be resulting from the fact that most Snow Goose Festival visitors originate from nearby Edmonton, home to the province's largest university. Compared to Tofield, Parksville-Qualicum may benefit more because older visitors spend more on festival activities than younger visitors (Chhabra, Sills, \& Rea, 2002). The gender difference may be due, in part, to the focus on guided activities at the Snow Goose Festival because slightly more women than men took guided trips at this festival. The Canadian Tourism Commission (2003) also found that, for outdoor and adventure travel, females were more likely to take guided tours than men. As well, the wildlife wood carving competition at the Brant Festival may have attracted more men than women.

Some limitations to this study should be recognized. First, while we tried to select festivals with many similarities, some differences remained between the two sites, most notably the high level of tourism infrastructure present in the Parksville-Qualicum area. Second, the Snow Goose Festival produced a higher sample size and response rate than the Brant Festival because the activities and locations were more centralized and provided easier access to interview visitors. Third, we did not adjust the expenditures to account for the 3-year gap between the two case studies; on the other hand, the changes produced by inflation over that time period were relatively small.

In conclusion, wildlife festival organizers need to know the characteristics of visitors to optimize economic benefits for organizers as well as local businesses. Patterns of expenditures, motivations, activities, and demographics vary considerably from festival to festival. Once these patterns are known at a specific site and compared fairly to other sites, valuable lessons can be drawn from the comparisons (Baum, 1999). For example, organizers can offer activities (e.g., appropriate rigor, variety, competitiveness) that cater to the visitors' motives and levels of skill, familiarity, and ability at each festival. Organizers can ensure that visitors are aware of accommodation, products, and services appropriate to their needs. Such attention to detail should increase visitor satisfaction and local benefits, by way of greater local expenditures. Moreover, knowledge of those economic benefits can assist in protecting wildlife (e.g., Clark, 1987; Kingsmill, 1988). Ultimately, increased understanding of visitors and their economic benefits should facilitate, in some fashion, the maintenance of wildlife, habitats, and communities upon which these festivals depend, so that the resulting visitor and community benefits are sustainable (Hvenegaard \& Dearden, 1998; Millar, 2003; O'Sullivan \& Jackson, 2002).

\section{References}

Baum, T. (1999). Themes and issues in comparative destination research: The use of lesson-drawing in comparative tourism research in the North Atlantic. Tourism Management, 20, 627-633.

Bryan, H. (1977). Leisure value systems and recreational specialization: The case of trout fishermen. Journal of Leisure Research, 9(3), 174-187.

Burr, S. W., \& Scott, D. (2004). Application of the recreational specialization framework to understanding visitors to the Great Salt Lake Bird Festival. Event Management, 9, 27-37.

Canadian Tourism Commission. (2003). IATOS 2003 outdoor enthusiast survey. Ottawa, ON: Author.

Chambliss, K., Slotkin, M. H., \& Vamosi, A. R. (2005). The economic impact of the 8th annual Space Coast Birding \& Wildlife Festival. Melbourne, FL: Florida Institute of Technology.

Chhabra, D., Sills, E., \& Cubbage, F. W. (2003). The significance of festivals to rural economies: Estimating the economic impacts of Scottish Highland Games in North Carolina. Journal of Travel Research, 41, 421-427.

Chhabra, D., Sills, E., \& Rea, P. (2002). Tourist expenditures at heritage festivals. Event Management, 7, 221-230.

Clark, W. R. (1987). Economics and marketing of 'Canada's Capistrano.' In A. W. Diamond \& F. L. Filion (Eds.), The value of birds (pp. 31-48). Cambridge, UK: International Council for Bird Preservation.

DeCray, S., Green, P., \& Payne, R. H. (1998, December). The birding festival: An opportunity waiting. Birding, 525-526.

DiGregorio, L. (2002). Birding festivals beckon. Birding, 34(1), 77.

Eubanks. T., \& Stoll, J. R. (1999). Avitourism in Texas. Retrieved April 20, 2005, from http://www.fermatainc.com/basic/ eco_avitourism.html

Fermata, Inc. (2001). A survey of two California nature festivals. Austin, TX: Author.

Fisby, W., \& Getz, D. (1989). Festival management: A case study perspective. Journal of Travel Research, 28(1), 7-11.

Gursoy, D., Kim, K., \& Uysal, M. (2004). Perceived impacts of festivals and special events by organizers: An extension and validation. Tourism Management, 25, 171-181.

Hvenegaard, G. T. (2002). Birder specialization differences in conservation involvement, demographics, and motivations. Human Dimensions in Wildlife, 7(1), 21-36.

Hvenegaard, G. T., Butler, J. R., \& Krystofiak, D. K. (1989). The economic values of bird watching at Point Pelee National Park, Ontario. Wildlife Society Bulletin, 17, 526-531.

Hvenegaard, G. T., \& Dearden, P. (1998). Linking ecotourism and biodiversity conservation: A case study of Doi Inthanon National Park, Thailand. Singapore Journal of Tropical Ge- 
ography, 19(2), 193-211.

Kim, C., Scott, D., Thigpen, J. F., \& Kim, S.-S. (1998). Economic impact of a birding festival. Festival Management \& Event Tourism, 5, 51-58.

Kingsmill, S. (1988). Swallowton: Pembroke, Ontario-the San Juan Capistrano of the North. Birder's World, 2(1), 10-13.

Long, P. T., \& Perdue, R. R. (1990). The economic impact of rural festivals and special events: Assessing the spatial distribution of expenditures. Journal of Travel Research, 28(4), 10-14.

Lynch, T., \& Harrington, J. (2003). The economic impact of the Florida Wakulla Springs Birding and Wildflower Festival. Tallahassee, FL: Center for Economic Forecasting and Analysis.

Lynch, T., Harrington, J., Chambliss, K., Slotkin, M. H., Vamosi, A. R. (2003). The economic impact of the 2nd annual Florida Panhandle Birding and Wildflower Festival. Tallahassee, FL: Center for Economic Forecasting and Analysis.

McFarlane, B. L. (1996). Socialization influences of specialization among birdwatchers. Human Dimensions of Wildlife, $1(1), 35-50$.

Millar, N. S. (2003). How to organize a birding or nature festival. Colorado Springs, CO: American Birding Association.

National Fish and Wildlife Foundation. (1999). 1999 Directory of birding and nature festivals. Washington, DC: Author.

Nicholson, R., \& Pearce, D. G. (2000). Who goes to events: A comparative analysis of the profile characteristics of visitors to four South Island events in New Zealand. Journal of Vacation Marketing, 6, 236-253.

O'Sullivan, D., \& Jackson, M. J. (2002). Festival tourism: A contributor to sustainable local economic development? Journal of Sustainable Tourism, 10(4), 325-342.

Pearce, D. G. (1993). Comparative studies in tourism research. In D. G. Pearce \& R. W. Butler (Eds.), Tourism research: Critiques and challenges (pp. 20-35). London: Routledge.

Portney R. P. (1994). The contingent valuation debate: Why economists should care? Journal of Economic Perspectives, 8(4), 3-17.
Romero, A., \& Stangel, P. (1996, January). Festival birding. Wildbird, 34-39.

Scott, D., \& Thigpen, J. (2003). Understanding the birder as tourist: Segmenting visitors to the Texas Hummer/Bird Celebration. Human Dimensions of Wildlife, 8, 199-218.

Statistics Canada. (2005). Population 15 years and over by highest level of schooling (1981-2001 Censuses). Retrieved June 13, 2006 from http://www40.statcan.ca/101/cst01/educ45.htm

Statistics Canada. (2006a). 2001 community profiles. Retrieved June 21, 2006 from http://www12.statcan.ca/english/profil01/ CP01/Index.cfm?Lang=E

Statistics Canada. (2006b). Age and sex, percentage distribution for both sexes, for Canada, provinces and territories. Retrieved June 21, 2006 from http://www40.statcan.ca/101/ cst01/demo10a.htm

Stevens, T. H., Echeverria, J., Glass, R. J., Hager, T., \& More, T. A. (1991). Measuring the existence value of wildlife: What do CVM estimates really show? Land Economics, 67(4), 390400.

Uysal, M., \& Gitelson. R. (1994). Assessment of economic impacts: Festivals and special events. Festival Management \& Event Tourism, 2, 3-9.

Ward, P., Radcliffe, G., Kirkby, J., Illingworth, J., \& Cadrin, C. (1998). Sensitive ecosystems inventory: East Vancouver and Gulf Islands 1993-1997. Volume 1: Methodology, ecological descriptions and results. Technical Report Series No. 320. Victoria, BC: Canadian Wildlife Service, Pacific and Yukon Region.

Warwick, D. P., \& Osherson, S. (1973). Comparative analysis in the social sciences. In D. P. Warwick \& S. Osherson (Eds.), Comparative research methods (pp. 3-41). Englewood Cliffs, NJ: Prentice-Hall.

Wiedner, D., \& Kerlinger, P. (1990). Economics of birding: A national survey of active birders. American Birds, 44(2), 209213.

Yukon Department of Environment. (2006). Celebration of Swans 2005 visitor survey analysis. Report MR-06-01. Whitehorse, Yukon: Yukon Fish and Wildlife Branch. 